\title{
Inconsistency of Prison Criminal Sanctions for Children and Criminal Objectives in RKUHP
}

\author{
Ani Triwati \\ University of Semarang, Indonesia \\ e-mail: anitriwati@gmail.com
}

\begin{abstract}
Anak merupakan kelompok yang rentan ketika berhadapan dengan sistem peradilan pidana berdasarkan berbagai analisis. Oleh karena itu dibutuhkan mekanisme khusus untuk melindungi kepentingan anak-anak yang berhadapan dengan hukum. Ditegaskan dalam Peraturan-Peraturan PBB bagi Perlindungan Anak yang Kehilangan Kebebasannya (United Nations Rules For The Protection of Juveniles Deprived of Their Liberty) bahwa, Sistem pengadilan anak harus menjunjung tinggi hak-hak dan keselamatan serta memajukan kesejahteraan fisik dan mental anak. Hukuman penjara harus digunakan sebagai upaya terakhir. Anak yang berkonflik dengan hukum, akan mendapatkan label atau stigmatisasi dari masyarakat mulai saat kasus berproses di tingkat kepolisian sampai putusan pengadilan bahkan mungkin selamanya. Artikel ini akan membahas mengenai Implikasi atas inkonsistensi sanksi penjara bagi anak dan tujuan pemidanaan dalam RKHUP, bahwa anak yang berproses dalam peradilan pidana, maka label akan melekat tanpa batas waktu, sehingga kemungkinan besar anak cenderung untuk melakukan tindak pidana lagi. Pidana penjara akan membawa anak untuk belajar lebih banyak pada lingkungannya.
\end{abstract}

Keywords: Inkonsistensi, Pidana penjara anak, Tujuan Pemidanaan 
Children are vulnerable groups when dealing with the criminal justice system based on various analyzes. Therefore a special mechanism is needed to protect the interests of children facing the law. It is affirmed in the UN Regulations for the Protection of Children Who Lost their Freedom that the child court system must uphold rights and safety and promote the physical and mental well-being of children. Prison sentences must be used as a last resort. Children who are in conflict with the law, will get a label or stigmatization from the community from the moment the case processes at the police level until the court ruling is even possible forever. This article will discuss the implications of inconsistencies in prison sanctions for children and the purpose of criminal prosecution in RKHUP, that children who proceed in criminal justice, the label will be inherent indefinitely, so it is likely that children tend to commit criminal acts again. Prison sentences will bring children to learn more about their environment.

Keywords: Inconsistency; criminal imprisonment; criminal purpose

\section{Introduction}

The state has an obligation to protect and fulfill the rights of children, including the rights of children in conflict with the law. RI Law Number 11 Year 2012 concerning the Criminal Justice System for Children states that children who are in conflict with the law are children who are in conflict with the law; children who are victims of crime; and children who witness criminal acts. Children who are in conflict with the law are children who are 12 (twelve) years old, but not yet 18 (eighteen) years old who are suspected of committing criminal offenses. This paper will focus on imprisonment sanctions for children in conflict with the law.

To protect the best interests of children who are in conflict with the law and avoid stigmatization, the state continues to reform criminal law, especially in the juvenile criminal justice system. Renewal of criminal law in essence implies, namely an attempt to re-orient and reform criminal law in accordance with the central socio-political, socio-philosophical and sociocultural values of the Indonesian people which underlie social policies, criminal policies, and law enforcement policies in Indonesia (Arief 2014: 29). The renewal of criminal law must be carried out in accordance with the values that live in society. 
Facing children in conflict with the law, it is necessary to make a wise solution so as not to cause negative consequences for children. Labels or stigmatization will be obtained by children who are in conflict with the law, from the commencement of the investigation process at the investigation level until the child has carried out criminal sanctions or actions decided by the court.

Facing children in conflict with the law, it is necessary to make a wise solution so as not to cause negative consequences for children. Labels or stigmatization will be obtained by children who are in conflict with the law, from the commencement of the investigation process at the investigation level until the child has carried out criminal sanctions or actions decided by the court.

The goals of the state listed in the Preamble to the 1945 Constitution of the Republic of Indonesia, among others, are to protect the entire nation of Indonesia and all of Indonesia's blood, to promote public welfare, and to educate the nation's life. These goals include those for children in conflict with the law.

The law is one of the means to achieve the goals of the state, so that the renewal of the criminal law in particular the renewal of the juvenile criminal justice system is to protect, advance welfare and educate children in conflict with the law. The draft Criminal Code (RKUHP) is a renewal of Indonesia's criminal law, where the current Penal Code is still a legacy from the colonial. RKUHP contains criminal sanctions for children who are in conflict with the law in the form of principal and additional crimes. Article 122 of the 2015 RKHUP states that basic crimes consist of commemorative penalties, crimes with conditions (guidance outside the institution, community service or supervision), job training, guidance within institutions, and prisons. Additional crimes for children in conflict with the law consist of deprivation of profits derived from criminal acts or fulfillment of customary obligations.

In the RKHUP, it still includes prison sanctions as one of the main criminal sanctions for children. RKHUP also explicitly formulates guidelines and objectives of criminal punishment. The existence of sanctions imprisonment for children who are in conflict with the law and explicitly formulated the purpose of punishment, according to the author 
there are inconsistencies in the RKUHP, namely between the main criminal penalties for children in conflict with the law and the purpose of punishment. If the aspects of protection and interests of children in conflict with the law are the main things that must be prioritized, there should be harmonization between the criminal sentences against children in conflict with the law and the purpose of punishment.

This paper focuses on two things, namely, the inconsistency of imprisonment sanctions for children and the purpose of punishment in RKHUP and the implications for the inconsistency of imprisonment sanctions for children and the purpose of punishment.

\section{Inconsistency of imprisonment for children and the purpose of punishment}

The three main problems in criminal law are crime, error and crime. Criminal conviction because of criminal acts and mistakes. Criminal sentences should have been adjusted to the purpose of punishment, including the purpose of punishment for children. Criminal objectives are part of the criminal system. Criminal objectives are part (sub-system) of the entire criminal system (criminal law system) in addition to other subsystems, namely the sub-system of criminal acts, criminal liability (error), and criminal (Arief 2015: 3). As part of the criminal justice system, criminal objectives should be formulated in the law.

The Criminal Code does not currently formulate explicit criminal guidelines and objectives. Thus, people (children) can be convicted, because of criminal acts and mistakes. In the development of society, bringing renewal of applicable law is needed, so that in imposing a crime, the judge can consider these matters in addition to the existence of 'criminal acts' and' mistakes. Thus, the judge in imposing a criminal offense is not only based on the existence of criminal acts and mistakes, but also the guidelines and objectives of criminal punishment.

The formulation of guidelines and objectives of criminalization in RKHUP certainly brings the consequence that a crime is imposed not only because of a criminal offense and error, but also based on the guidelines and purpose of punishment. With the inclusion of the objective variable in the 
criminal terms, according to the concept, the basis for justification or justification for the crime is not only in criminal acts (objective conditions) and errors (subjective conditions), but also in criminal goals or guidelines (Arief 2015: 14).

The theory of punishment itself in the Continental European legal system is called absolute theory, relative theory and combined theory. The main basis of the absolute approach is revenge against the perpetrators, or in other words, the basis for justification of the crime lies in the presence or occurrence of the crime itself (Ali 2012: 187). The criminal sentence was dropped because the perpetrator had committed a crime, or the criminal was handed down in retaliation for the crime that had been committed.

Relative theory in principle teaches that criminal offense and its implementation must at least be oriented to efforts to prevent convicted (special prevention) from the possibility of repeat crime again in the future, as well as prevent the general public in general (general prevention) from the possibility of committing good crimes such as crimes that have been committed convict and others (Ali 2012: 190). Combined theory is a combination of the goals of absolute theory and relative theory. Aside from being a retaliation for a criminal offense, a combined theory is also a preventive measure to prevent another crime occurring both by the perpetrators and other community members.

RI Law No. 11 of 2012 concerning the Juvenile Justice System has accommodated the settlement of criminal acts committed by children with the existence of restorative justice and diversion. In addition, the regulation also formulates criminal sanctions and actions. The formulation of criminal sanctions and actions in the law are the same as those in the 2015 RKUHP. In essence, both of them include imprisonment as the last alternative for children in conflict with the law.

Criminalization of children in conflict with the law is also based on the purpose of punishment. Article 55 of the Criminal Code Criminal Procedure Code mentions the purpose of punishment, namely:

a. prevent criminal acts by upholding legal norms for the protection of the community; 
b. popularize the convicted person by holding coaching so that he becomes a good and useful person;

c. resolve conflicts caused by crime, restore balance, and bring a sense of peace in society; and

d. free the guilty convict.

In the first goal, which is to prevent the commission of criminal acts by enforcing legal norms in order to protect the community. Prevention or preventive action is carried out by applying legal norms, so that it is expected that by applying legal norms, it can cause a deterrent effect for the perpetrators or other members of the community so as not to commit a criminal offense. The application of legal norms for children in conflict with the law, according to the author, may not necessarily prevent a crime.

Children who are in conflict with the law, will get a label or stigmatization from the community starting from cases proceeding at the police level. According to labeling theory, juvenile delinquency can arise because of the 'naughty' stigma of parents, neighbors, friends, relatives, teachers or the community, even court decisions (Sutatiek 2013: 46). The labeling theory approach can be divided into two parts, namely the issue of how and why a person gets a stamp or label and the effect of labeling on the deviation of subsequent behavior (Atmasasmita 2013: 49).

Crimes committed by children for the first time, can continue for the second and so on, because of the label that has been given by the environment including the court's decision. Penalty sanctions imprisonment as the application of legal norms for children, does not guarantee it will give a deterrent effect for perpetrators to not commit criminal acts again. The deterrent effect is not due to imprisonment imposed or the application of legal norms, labeled as a 'bad' or 'wrong' child or ex-convict attached to a child in conflict with the law, which will lead the child to commit the next crime.

The next goal of punishment is to popularize the convict by holding coaching so that they become good and useful people. For children who are in conflict with the law, it will be difficult to re-interact with their environment. This is due to the labeling effect that has been inherent from 
the beginning of the child proceeding at the police level to the court's decision. Even people who have grown up will find it difficult to return to their communities, especially children who tend to return to a crime environment that is considered more able to accept the situation than to a society that has given it an evil label.

Any person who has admitted his mistakes and wants to return to a normal life, wants to be a useful child, becomes difficult if the community does not open their hands because of the label. Thus, the state should review the sanctions imprisonment for children, even though the prison sentence is the last alternative.

Other goals of punishment are to resolve conflicts caused by criminal acts, restore balance, and bring a sense of peace in the community. The state has adopted a policy in the resolution of criminal acts committed by adults and children. The Law on the Juvenile Justice System has accommodated the settlement of criminal acts committed by children. Nevertheless, the existence of sanctions imprisonment for children who are in conflict with the law, on the one hand can resolve conflicts but on the other hand can lead to new problems namely the tendency to commit more criminal acts.

Stigmatization or labels that have been obtained by children in conflict with the law since the beginning of the examination process, tend to make children commit further crimes. The stigmatization given by the community makes the child feel innocent, so because the label or stigmatization makes the child commit further crimes.

In addition, if the prison sentence as a final alternative is imposed by the judge, the child can learn about the behavior of the social environment inside the prison and feel the same boat with his new environment. This is one possibility for children to commit criminal acts again because intentionally or not, the child will learn deviant behavior in their environment.

Cooperation between related parties including policy makers is needed to create balance and bring a sense of peace for the community, in dealing with children who are in conflict with the law. Openness of the community, not labeling or stigmatization and the role of relevant institutions in solving 
nonpenal solutions to children in conflict with the law, can provide comfort for both children and their community environment.

The formulation of the purpose of punishment in RKHUP is intended so that in each decision the judge can consider the purpose of the punishment itself. Likewise, the existence of sanctions imprisonment for children who are in conflict with the law, can lead to inconsistencies with the goal of punishment. Children in general have limited or immature thinking in thinking, so that in behaving or deviating yet or even not thinking about the consequences that will occur. If a serious crime is committed and the sentence given is imprisonment, it tends to result in worsening the future of the child and will then commit another crime. Thus, imprisonment for children in conflict with the law needs to be reexamined so that it is consistent with the purpose of punishment.

\section{Implications of inconsistency in imprisonment for children and criminal purpose}

Guided by the Pancasila as the nation's view of life, should resolve criminal acts, especially those committed by children, also returned to Pancasila. The legal system should also be based on the values that live in our society, which are the basis of the nation's view of life. According to Satjipto Rahardjo (2006: 10), we use the understanding of the 'Pancasila law' system to accommodate various characteristic values that our legal system seeks to embody such as kinship, fatherhood, balance harmony, and deliberation. These values are the roots of our legal culture.

The settlement of a crime committed by a child based on the values that live in the community, better protects the interests and rights of children, so that in addition to solving problems, it can also be used as a means of prevention. Non-familiar settlement, can prevent children from stigmatization, repeating criminal acts, maintaining balance and fostering a sense of peace in society.

Several international instruments regulate the prevention and treatment of children in conflict with the law. Several international instruments, including the United Nations Guidelines for the Prevention of Juvenile Delinquency (The Riyadh Guidelines), are listed in UN Resolution 45/112 of 
December 14, 1990, which contains the basic principles on which to prevent child delinquency. Furthermore, The United Nations for the Administration of Juvenile Justice (The Beijing Rules) listed in UN Resolution 40/33 dated 29 November 1985, among others, contains the need for comprehensive social policies that can avoid or distance children from the juvenile justice system and criminal justice the prison is attempted as a last resort and only for a short time.

All forms of deprivation of liberty against children must be based on human rights and the avoidance of side effects due to detention in the criminal justice process, so that minimum standards for the protection of children who commit a criminal offense are required, as stipulated in the United Nations Rules for the Protection of Juvenile Deprived of Their Liberty, as set out in UN Resolution 45/113, December 14, 1990.

Referring to these international instruments, it can be concluded that in essence, children who are in conflict with the law, both for prevention and handling, must prioritize the interests of children, protect children's rights, and settlements using nonpenal means. Thus, sanctions imprisonment could be a last resort. According to the author, it would be better if the penal sanctions imprisonment were not formulated as criminal sanctions for children in conflict with the law.

As a comparison, in Greece the formulation of sanctions or criminal threats and actions as stated by Koesno Adi (2014: 66), as follows:

a. Young perpetrators can be punished by:

1. Reformative actions;

2. Care Measures;

3. Detention in an orphanage

b. Reformative measures:

1. Stern reprimand / insults;

2. Placement under the supervision of parents / guardians;

3. Placement in the supervisory / foundation representative or special committee; 
4. Placement in the appropriate state / township / community environment, or private education institutions.

Criminal sanctions for children in Greece do not include imprisonment or confinement. Young perpetrators between the ages of 7-18 years are punished with reformative measures, treatment measures, and those aged 13 years or older are subject to detention in an orphanage or confinnement in a reformatory (Adi 2014: 65). Reformative actions in the form of loud reprimands / slurs, placement under the supervision of parents / guardians, placement in representatives of special supervision / foundations or committees, placement in the appropriate state / township / community environment, or private education institutions. For the implementation of reformative measures, the state must facilitate with adequate means.

The Netherlands does not include imprisonment as the main crime, but confinement to crime. Imprisonment penalties are also given an alternative form of fines, so that judges can impose criminal fines without being accompanied by imprisonment. For violations, the main criminal formulation is in the form of criminal fines.

Formulation of criminal sanctions and actions for children in legislation in the Netherlands (Adi 2014: 61-62, namely:

a. Principal crime, article $77 \mathrm{~h}$ paragraph (1):

1. for crimes in the form of child custody or fines,

2. for violations in the form of fines.

b. Substitute of principal crime, article $77 \mathrm{~h}$ paragraph (2):

1. social work or community service,

2. work to repair damage,

3. attend a training project.

c. For additional crimes, article $77 \mathrm{~h}$ paragraph (3):

1. deprivation,

2. SIM revocation,

d. Actions, article $77 \mathrm{~h}$ paragraph (4):

1. placement in a special institution for children,

WALISONGO LAW REVIEW (WALREV) Vol 01 No 1 April 2019 || 42 
Ani Triwati, Inconsistency of Prison Criminal Sanctions for Children...

2. confiscation,

3. deprivation of profits from unlawful acts,

4. compensation or compensation for damage / loss.

Based on the values that exist in our society, various international instruments and the comparison of criminal sanctions for children in conflict with laws in Greece and the Netherlands, it is better if the formulation of imprisonment sanctions in the RKUHP be abolished. This is a step so that the goal of punishment is achieved.

In addition to the purpose of punishment, the RKHUP also formulates criminal guidelines. Criminal guidelines contain instructions on what should be considered in imposing a crime (Arief 2012: 97). Regarding criminal guidelines in RKHUP, Article 56 states that:

a. In punishment must be considered:

1. Mistake makers of crime;

2. Motive and purpose of committing a crime;

3. The inner attitude of the makers of criminal acts;

4. Crimes committed whether planned or unplanned;

5. How to commit a crime;

6. The attitudes and actions of the makers after committing a crime;

7. Curriculum vitae, social conditions, and economic conditions of the makers of criminal acts;

8. Criminal influence on the future of the makers of criminal acts;

9. Influence of criminal acts against the victim or the victim's family;

10. Forgiveness of victims and / or their families; and / or

11. The public's view of the crime committed.

b. The mildness of the act, the personal condition of the maker, or the state at the time the act was committed or what happened next, can 
be used as a basis for consideration not to impose a criminal act or impose an action by considering aspects of justice and humanity.

Criminal guidelines and criminal objectives in the RKUHP can provide a special color especially for judges in imposing criminal sanctions on children in conflict with the law. By keeping in mind the objectives and guidelines for punishment, according to the concept, in certain conditions, the judge is still given the authority to apologize and not to impose criminal or any action, even though the crime and error have been proven (Arief, 2012: 14).

Implications for inconsistency in prison sanctions for children and the purpose of punishment in RKHUP, that children who proceed in criminal justice, the label will be attached indefinitely, so it is likely that children are more likely to commit criminal acts again. Criminal prison will bring children to learn more in their environment.

Thus, the objective of punishment basically consists of two main aspects, namely the aspect of community protection against criminal acts and aspects of protection / fostering individual criminal offenses (aspects of criminal individualization). The aspect of criminal individualization includes the objectives of:

a. Rehabilitation, reeducation, re-socialization of the convict, among others: so as not to commit acts that damage / harm oneself or others / society and to be virtuous (moral) Pancasila;

b. Freeing guilt;

c. Protect the perpetrators from the imposition of arbitrary or inhumane sanctions or reprisals (crimes are not intended to depict and degrading human dignity) (Arief 2012: 40-41).

The purpose of criminal punishment from the aspect of criminal individualization, according to the author, will focus more on the improvement and guidance of the perpetrators (children), so that in the future they will not commit criminal acts and prevent the perpetrators from criminal sanctions that are told.

\section{Conclusion}


From the discussion above, it can be explained that the inconsistency of imprisonment sanctions for children who are in conflict with the law and the purpose of punishment in the RKUHP, the application of legal norms for children who are in conflict with the law, may not necessarily prevent a crime. The deterrent effect is not due to imprisonment imposed or the application of legal norms, labeling as a naughty or wrong child or exconvict attached to a child in conflict with the law that will lead the child to commit the next crime, because there is no guilt so that it will not resolve the conflict and not cause a sense of peace for the community.

Then, the implications for inconsistency of imprisonment for children and the purpose of punishment in R-KHUP, can be explained that children who proceed in criminal justice, will be attached to a label or stigmatization without a time limit, so it is likely that children are more likely to commit another crime. Criminal prison will actually bring children to learn more in their environment.

Therefore, according to the author, it is important that policy makers in the renewal of criminal law no longer include penal sanctions for children in conflict with the law, taking into account the best interests and protection of children's rights. In addition, the aim of criminal punishment from the aspect of criminal individualization, according to the author, is more focused on the improvement and guidance of the perpetrators (children), so that criminal sanctions should be harmonized with the aim of criminalization so that the next child does not commit another criminal offense and avoid imprisonment. [w] 
Ani Triwati, Inconsistency of Prison Criminal Sanctions for Children...

\section{BIBLIOGRAPHY}

Adi, Koesno. 2014. Diversi Tindak Pidana Narkotika Anak. Malang: Setara Press.

Ali, Mahrus. 2012. Dasar-dasar Hukum Pidana, Jakarta: Sinar Grafika.

Arief, Barda Nawawi. 2012. Kebijakan Formulasi Ketentuan Pidana dalam Peraturan Perundang-undangan. Semarang: Pustaka Magister.

Arief, Barda Nawawi. 2014. Bunga rampai Kebijakan Hukum Pidana: Perkembangan Penyusunan Konsep KUHP Baru. Jakarta: Kencana Prenadamedia Group.

Arief, Barda Nawawi. 2015. Tujuan dan Pedoman Pemidanaan Perspektif Pembaharuan dan Perbandingan Hukum Pidana, Semarang: Pustaka Magister.

Atmasasmita, Romli, 2013. Teori dan Kapita Selekta Kriminologi, Bandung: PT Refika Aditama.

Rahardjo, Satjipto, 2006. Sisi Lain dari Hukum di Indonesia. Jakarta: Kompas.

Sutatiek, Sri, 2013. Rekonstruksi Sistem Sanksi dalam Hukum Pidana Anak di Indonesia, Yogyakarta: Aswaja Pressindo.

Pemerintah Republik Indonesia Nomor 11 tahun 2012 tentang Sistem Peradilan Pidana Anak.

Rancangan Undang-Undang tentang Kitab Undang-Undang Hukum Pidana Tahun 2015

United Nations Standard Minimum Rules for the administration of Juvenile Justice (The Beijing Rules), Resolusi PBB 40/33 tanggal 29 Nopember 1985.

The United Nations Guidelines for the Prevention of Juvenile Delinquency (The Riyadh Guidelines), tercantum dalam Resolusi PBB 45/112 tanggal 14 Desember 1990. 
Ani Triwati, Inconsistency of Prison Criminal Sanctions for Children...

United Nations Rules for the Protection of Juvenile Deprived of Their

Liberty, yang tertuang dalam Resolusi PBB 45/113, tanggal 14 Desember 1990. 
Ani Triwati, Inconsistency of Prison Criminal Sanctions for Children...

WALISONGO LAW REVIEW (WALREV) Vol 01 No 1 April 2019 || 48 